\title{
The impact of COVID-19 lockdown on the air quality of Eastern Province, Saudi Arabia
}

\author{
Ismail Anil ${ }^{1} \cdot$ Omar Alagha $^{1}$ (i) \\ Received: 9 August 2020 / Accepted: 21 August 2020 / Published online: 29 August 2020 \\ (C) Springer Nature B.V. 2020
}

\begin{abstract}
Since the identification of the COVID-19 outbreak in Wuhan, China, in December 2019, the death toll from the direct infection by COVID-19 has exceeded 775,000, and more than 21 million cases have been reported to the World Health Organization (WHO) around the world. It is strongly believed that its impact might be worsened by poor outdoor and indoor air qualities, particularly on older adults. The nationwide lockdown measures were imposed between March 23 and June 20, 2020, to stop the spread of COVID-19 pandemic in the Kingdom of Saudi Arabia (KSA). In this work, the possible effects of the lockdown on the air quality were investigated using meteorological and air quality datasets obtained from eight monitoring stations covering the Eastern Province of the KSA. The studied air pollutants include carbon monoxide (CO), sulfur dioxide $\left(\mathrm{SO}_{2}\right)$, nitrogen dioxide $\left(\mathrm{NO}_{2}\right)$, ozone $\left(\mathrm{O}_{3}\right)$, and inhalable particulate matter $\left(\mathrm{PM}_{10}\right)$. The $\mathrm{NO}_{2}$ was found to be the marker pollutant responding best to the lockdown measures since its concentrations decreased at all sites during- and post-lockdown periods and ranged between 12$86 \%$ and $14-81 \%$, respectively. Compared with pre-lockdown period, the Eastern Province also experienced significant concentration reductions at varying rates for $\mathrm{PM}_{10}(21-70 \%), \mathrm{CO}(5.8-55 \%)$, and $\mathrm{SO}_{2}(8.7-30 \%)$, while $\mathrm{O}_{3}$ concentrations showed increasing rates ranging between 6.3 and $45 \%$. The consequences of these reductions were reflected in easing the outdoor air quality, which might reduce the impact of COVID-19 pandemic, especially on elderly and sensitive groups.
\end{abstract}

Keywords COVID-19 $\cdot$ Sars-Cov-2 $\cdot$ Lockdown $\cdot$ Air pollution $\cdot$ Air quality $\cdot$ Saudi Arabia

\section{Introduction}

The World Health Organization (WHO) announced on Wednesday, March 11, 2020, the new coronavirus "COVID19" disease as "a global epidemic" (WHO 2020). In response to that, governments around the world have been taking a range of actions and measures, including the closing of schools, worship places, and workplaces, postponing and canceling huge public events, restricting public transport, the lockdown of movement of people, and ceasing domestic and international flights (Bherwani et al. 2020; Bashir et al. 2020a). According to many studies, the COVID-19 is believed to transmit through airborne bioaerosol droplets. Nevertheless, different parameters such as the extent of urban air pollution and weather conditions might have a significant

Omar Alagha

oaga@iau.edu.sa

1 Environmental Engineering Department, College of Engineering A13, Imam Abdulrahman Bin Faisal University, Main Campus, P.O. Box 1982, Dammam 34212, Saudi Arabia impact on the elevated rates of COVID-19 cases (Farhan Bashir et al. 2020; Fareed et al. 2020).

After the discovery of the first case of COVID-19 in the KSA on March 2, 2020, a series of actions were taken in response to the COVID-19 pandemic. The first three significant actions taken to control the spread of the pandemic were as follows: (i) suspension of Umrah pilgrimage (March 4), (ii) suspension of all schools and universities (March 8), and (iii) suspension of all international flights (March 9). With the spread of COVID-19 and the absence of vaccine and medication globally, the Saudi government imposed nationwide partial lockdown (from 7 PM to 6 AM) on March 23 followed by the restriction on movement between provinces on March 25 . After that, the full lockdown was imposed nationwide on April 6. On May 28, the lockdown was partially lifted in all cities except Mecca, the movement between regions was eased, and shopping malls were opened. Following this, prayers were allowed in mosques except for the Great Mosque of Mecca, and the restrictions on domestic flights, restaurants and cafes, and parks were eased on May 31. The latest action was on June 21, where the partial lockdown was lifted on all regions. However, international flights remain 
suspended except repatriation flights for residents. Lastly, the Pilgrimage (Haj) was allowed to domestic residents and Saudi nationals only with limited numbers (MoH 2020).

The COVID-19 lockdown measures affected many aspects of human activities including vehicle use, public transportation, and industrial processes (Pata 2020; Gautam 2020; Bashir et al. 2020b; Shehzad et al. 2020). In addition, several researchers around the world reported that there is a mitigation of air pollution during COVID-19 lockdown compared with before period. For instance, Berman and Ebisu (2020) assessed the air quality during the COVID-19 pandemic using air quality data, including $\mathrm{PM}_{2.5}$ and $\mathrm{NO}_{2}$, monitored in the USA between 2017 and 2020. The study found that statistically significant $\mathrm{PM}_{2.5}$ and $\mathrm{NO}_{2}$ reductions were noticed as $11 \%$ and $26 \%$, respectively. Shakoor et al. (2020) investigated the changes in levels of air pollutants before and after lockdown periods in USA and China. The results showed that CO, $\mathrm{NO}_{2}$, and $\mathrm{PM}_{2.5}$ concentration reduced by $19 \%, 37 \%$, and $1.1 \%$, respectively in USA, while $\mathrm{CO}, \mathrm{NO}_{2}, \mathrm{SO}_{2}, \mathrm{PM}_{2.5}$, and $\mathrm{PM}_{10}$ concentration decreased by $27 \%, 39 \%, 18 \%$, $18 \%$, and 38\%, respectively, in China. Agarwal et al. (2020) found that lockdown measures in India and China resulted in improvements for the air quality indexes of $\mathrm{PM}_{2.5}$ and $\mathrm{NO}_{2}$ by $65 \%$ and $66 \%$ in India and $45 \%$ and $37 \%$ in China, respectively. Singh and Chauhan (2020) analyzed air quality changes before and after COVID-19 lockdown measures over India using ground-level and satellite observations. Their results demonstrated that the $\mathrm{PM}_{2.5}$ concentrations dropped by to $35 \% \%$, compared with pre-lockdown phase. In another study, Sharma et al. (2020) studied the changes in concentrations of air pollutants before and after lockdown periods in seven cities of India. They reported that $\mathrm{PM}_{2.5}, \mathrm{PM}_{10}, \mathrm{NO}_{2}$, and $\mathrm{SO}_{2}$ reduced by $23-58 \%, 24-44 \%, 30-64 \%$, and $3.5-70 \%$, respectively. Zambrano-Monserrate and Ruano (2020) reported that $\mathrm{NO}_{2}$ and $\mathrm{PM}_{2.5}$ levels in Ecuador importantly reduced just after the implementation of lockdown measures. At the regional scale, researchers studied the effect of climatic parameters on the spread of COVID-19. Their result showed that transportation and population numbers have a forward association with the infection rates (Barbieri et al. 2020; Ahmadi et al. 2020).

This study focuses on investigating the possible effects of the lockdown due to the COVID-19 pandemic on the air quality using meteorological and air quality datasets in the Eastern Province of the KSA.

\section{Methodology}

\section{Description of the study area}

The Eastern Province is the easternmost of the thirteen provinces of the KSA and located between latitudes of $29.16^{\circ} \mathrm{N}$ and $19.11^{\circ} \mathrm{N}$ and longitudes of $44.65^{\circ} \mathrm{E}$ and $55.66^{\circ} \mathrm{E}$. The Eastern Province is the third most populated province with a total population of 4.9 million and the largest province (by area) of the KSA. The weather is hot in the summer season and mild for the rest of the seasons of the year. The long-term annual average values of the temperature and relative humidity are $27{ }^{\circ} \mathrm{C}$ and $41 \%$, respectively. Wind systems from northern directions dominate over the area with an average ground-level wind speed of $4.2 \mathrm{~m} / \mathrm{s}$. The region has an arid precipitation regime and receives a total of $100 \mathrm{~mm}$ rainfall in a year between November and April (Anil et al. 2019). The Eastern Province has been facing severe local and long-range dust storms because of the pressure gradients. During the summer season, hot, dry, and low-level northwesterly winds called "Shamal winds" blowing at a minimum speed of $10 \mathrm{~m} / \mathrm{s}$ lift dust and sand to the local and remote regions (Karaca et al. 2009; Anil et al. 2017, 2019). Remarkable amounts of $\mathrm{PM}_{10}$ have been inhaled during episodic periods, resulting in a tremendous rise in the number of hospital admissions regarding respiratory issues (Tsiouri et al. 2015). Tawabini et al. (2017) recently reported that the daily average $\mathrm{PM}_{10}$ concentrations of Dhahran, Khobar, and Dammam districts of the Eastern Province were 177,380 , and $126 \mu \mathrm{g} / \mathrm{m}^{-3}$, respectively, which were quite above than the WHO's daily $\mathrm{PM}_{10}$ guideline value of $50 \mu \mathrm{g} / \mathrm{m}^{-3}$ (WHO 2006).

\section{Air quality data and study period}

The air quality dataset discussed in this research was obtained from the database of the General Authority of Meteorology and Environment Protection (GAMEP) including $\mathrm{CO}, \mathrm{SO}_{2}$, $\mathrm{NO}_{2}, \mathrm{O}_{3}$, and $\mathrm{PM}_{10}$ in seven different locations of Eastern Province, which are Jubail (Station no. 1), Qatif (Station no. 2), Dammam (Stations nos. 3-5), and Al Ahsa (Stations nos. 7-8) cities. Furthermore, hourly concentrations of air pollutants have been measured and recorded at the fully automated mobile air quality monitoring station (Station no. 6) located inside the Dammam south campus of Imam Abdulrahman Bin Faisal University (IAU). The geographic locations of the air quality monitoring stations (AQMS) are given in Fig. 1. To reveal the impact of the lockdown due to the COVID-19 on the air quality, the obtained air quality datasets were divided into three periods: (i) pre-lockdown (September 15, 2019 March 22, 2020), (ii) during-lockdown (March 23, 2020 June 20, 2020), and (iii) post-lockdown (June 21, 2020-July $18,2020)$.

\section{Meteorology data}

The meteorology data of the region during the study period was recorded by using a Davis ${ }^{\circledR}$ Vantage Pro 2+ wireless meteorology station, located at the roof of the college of engineering building of IAU (Station no. 6). The wind rose plots 


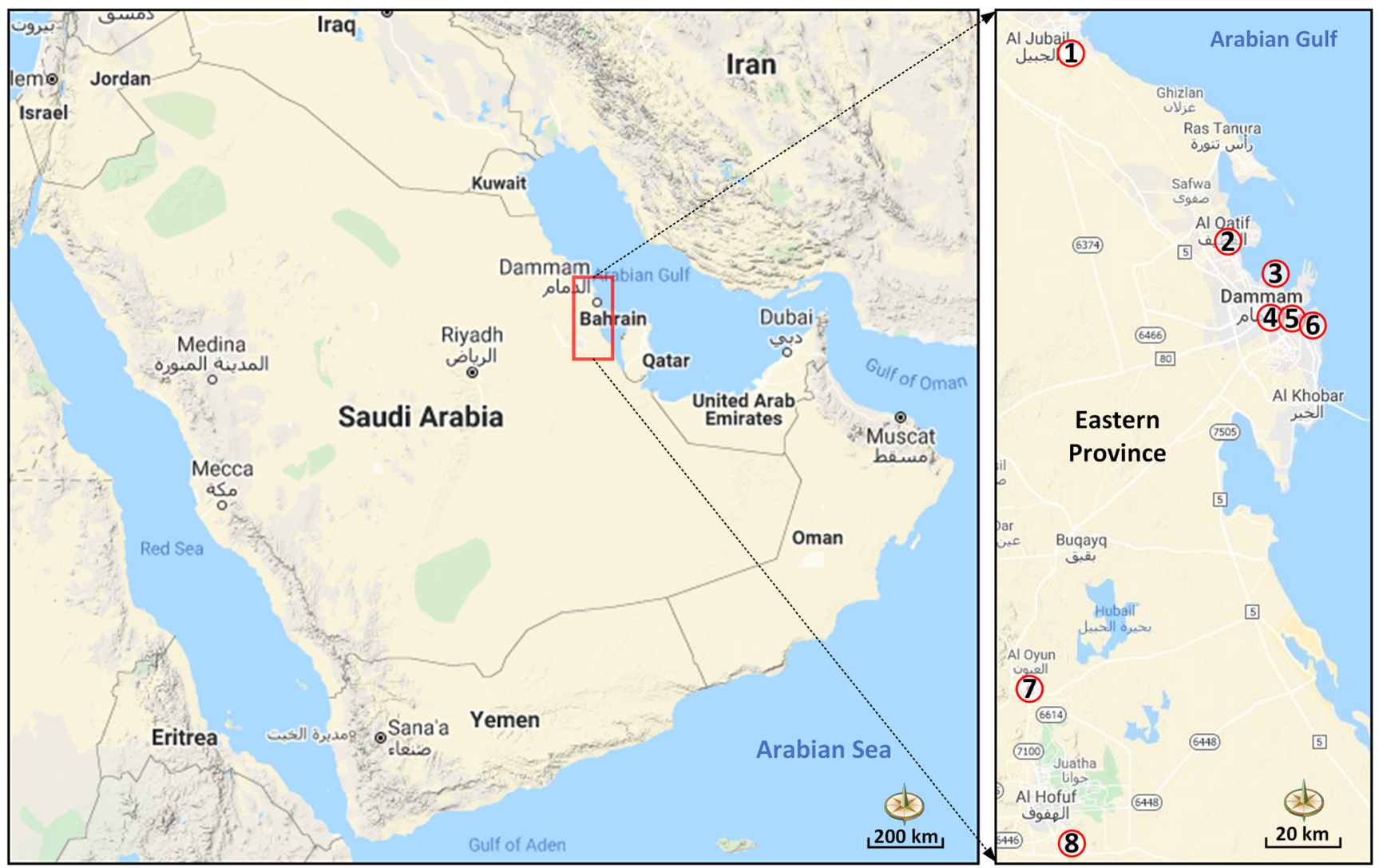

Fig. 1 Locations of air quality monitoring stations in the Eastern Province

for the study region during the whole study, pre-lockdown, lockdown, and post-lockdown periods are illustrated in Fig. 2. The northwesterly winds governed the wind regime during the pre-lockdown, lockdown, and post-lockdown periods with the frequencies of $48.8 \%, 50.5 \%$, and $58.6 \%$, respectively. The average wind speeds of pre-lockdown, lockdown, and postlockdown periods were calculated as $3.72( \pm 2.35), 4.51$ ( \pm $2.77)$, and $3.92( \pm 2.66) \mathrm{m} / \mathrm{s}$, respectively.

\section{Statistical analysis and data visualization}

Descriptive statistics and outlier analysis methods were performed on the obtained air quality data sets. Box and whisker plots were depicted using the calculated mean, median, first quartile, third quartile, the range within 1.5 times of interquartile range (IQR), and outliers of each pollutant observed at each station for pre-lockdown, lockdown, and postlockdown periods. Bivariate polar plots of concentrations were generated to determine the effect of wind velocity and wind direction data couple on the concentration of each pollutant during pre-lockdown, lockdown, and post-lockdown periods (Habeebullah et al. 2015; Nadzir et al. 2020; Omokungbe et al. 2020).

\section{Results and discussions}

\section{Concentration variations of air pollutants before, during, and after lockdown periods}

Descriptive statistics of each pollutant such as mean, median, first quartile, third quartile, the range within 1.5 times of interquartile range (IQR), and outliers are represented in box and whisker plots for pre-, during-, and post-lockdown periods (Fig. 3). During the whole study period between September 15, 2019, and July 18, 2020, the mean and median $\mathrm{CO}$ concentrations ranged between 0.16 and $0.14 \mathrm{ppm}$ (IAUUrban station), respectively, and between 2.34 and $2.04 \mathrm{ppm}$ (Dammam-Coastal), respectively, and were quite lower than the maximum daily 8-h mean value of European Union (Directive 2008/50/EC) (EU 2008). The observed CO concentrations indicated distinct spatial and temporal variation patterns before, during, and after lockdown periods. The highest $\mathrm{CO}$ concentration decrease during the lockdown was found for Qatif ( $\downarrow 0.96 \mathrm{ppm})$, followed by Rakah ( $\downarrow 0.33 \mathrm{ppm}), \mathrm{Al}$ Ahsa-Industrial $(\downarrow 0.24 \mathrm{ppm})$, and IAU $(\downarrow 0.12 \mathrm{ppm})$ sites as compared with the pre-lockdown period. On the other hand, the mean $\mathrm{CO}$ concentration at the Jubail site gradually increased by $0.50 \mathrm{ppm}$ during the lockdown and $0.93 \mathrm{ppm}$ 

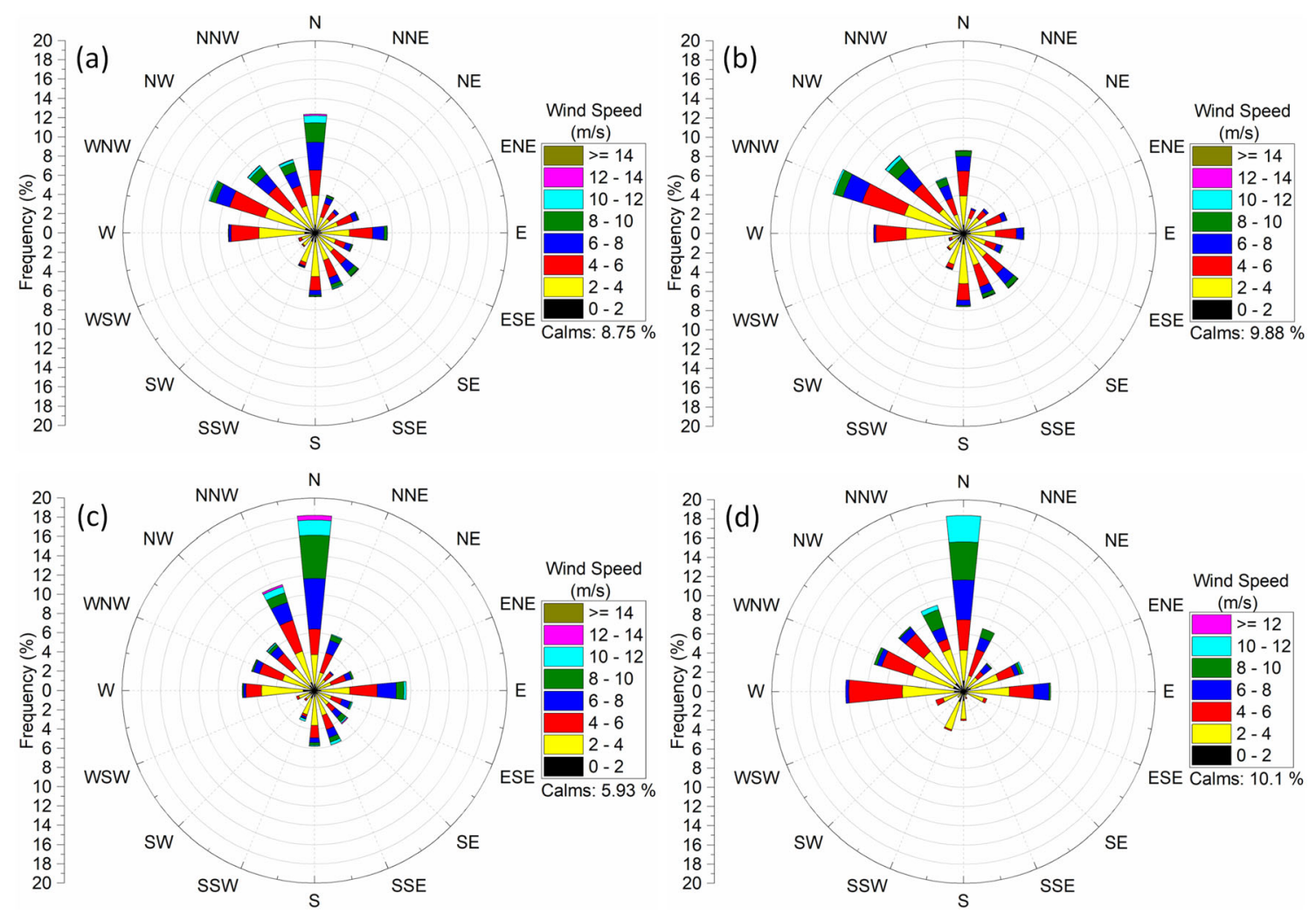

Fig. 2 Wind rose plots for the study region during: a the whole study, b pre-lockdown, $\mathbf{c}$ lockdown, and $\mathbf{d}$ post-lockdown periods

post-lockdown phases. In addition to this, mean $\mathrm{CO}$ concentrations at Rakah site before and after lockdown periods increased from 1.65 to $2.48 \mathrm{ppm}$. The fluctuations of mean CO concentrations at Al Ahsa-Traffic, Dammam-Coastal, and Dammam-Industrial stations were not statistically significant within pre-, during-, and post-lockdown periods.

As observed in $\mathrm{CO}$ concentrations, temporal and spatial changes of $\mathrm{SO}_{2}$ concentrations were quite different. Almost all sites exhibited mild outlier values before, during, and after lockdown periods with an average of mild to extreme outliers of three points. Compared with the pre-lockdown period, the IAU site indicated the highest $\mathrm{SO}_{2}$ concentration reduction $(\downarrow 1.38 \mathrm{ppb})$ during the lockdown, followed by Qatif ( $\downarrow 0.64 \mathrm{ppb})$, Jubail $(\downarrow 0.41 \mathrm{ppb})$, Dammam-Industrial $(\downarrow 0.21 \mathrm{ppb})$, and Al Ahsa-Industrial ( $\downarrow 0.16 \mathrm{ppb})$ sites. On the contrary, in comparison with the pre-lockdown period, mean $\mathrm{SO}_{2}$ concentrations gradually increased by $2.58 \mathrm{ppb}$ (mean: $0.88 \mathrm{ppb})$ and $13.5 \mathrm{ppb}(8.18 \mathrm{ppb})$ at Rakah and by $0.88 \mathrm{ppb}$ (mean: $0.74 \mathrm{ppb})$ and $1.25 \mathrm{ppb}(1.10 \mathrm{ppb})$ at Dammam-Coastal sites during the lockdown and postlockdown phases, respectively. The highest $\mathrm{SO}_{2}$ concentration increase during the lockdown was noticed for the $\mathrm{Al}$ Ahsa-Traffic site ( $\uparrow 3.39 \mathrm{ppb})$ as compared with the prelockdown period. As was observed for Rakah and Dammam-Coastal sites, the mean $\mathrm{SO}_{2}$ concentrations within the post-lockdown phase at Al Ahsa-Traffic, Qatif, and Al Ahsa-Industrial sites increased by $2.55,1.69$, and $0.62 \mathrm{ppb}$, respectively, with respect to the pre-lockdown period. It is noteworthy to mention that only the mean $\mathrm{SO}_{2}$ concentration at the Rakah site during the post-lockdown period $(41.9 \mu \mathrm{g} /$ $\mathrm{m}^{-3}$ ) was higher than the WHO's daily $\mathrm{SO}_{2}$ guideline value of $20 \mu \mathrm{g} / \mathrm{m}^{-3}$ (WHO 2006). The increased concentrations noticed for $\mathrm{CO}$ and $\mathrm{SO}_{2}$ pollutants at few locations could be linked to the large spectrum of industrial activities generating variable emission rates since most of the essential facilities were not shut down during the lockdown period.

The impact of the lockdown period was most obvious on $\mathrm{NO}_{2}$ concentrations over the Eastern Province. The mean $\mathrm{NO}_{2}$ concentrations during pre-lockdown period were in the following order: $81.7 \pm 82.8 \mathrm{ppb}$ (Jubail) $>30.1 \pm 20.6 \mathrm{ppb}$ $($ Rakah $)>21.5 \pm 5.43 \mathrm{ppb}(\mathrm{IAU})>8.85 \pm 9.30 \mathrm{ppb}(\mathrm{Al}$ Ahsa-Traffic) $>5.49 \pm 3.52 \mathrm{ppb}$ (Dammam-Industrial) $>$ $4.59 \pm 2.64 \mathrm{ppb}$ (Al Ahsa-Industrial) $>3.84 \pm 0.68 \mathrm{ppb}$ (Dammam-Coastal) $>3.29 \pm 1.03 \mathrm{ppb}$ (Qatif). At all monitoring sites, mean $\mathrm{NO}_{2}$ concentrations considerably decreased during the lockdown and post-lockdown phases in reference to the pre-lockdown phase. The magnitude of decrease in mean $\mathrm{NO}_{2}$ concentrations was as high as about 62.5 (median: 69.3), 25.1 (25.7), and 10.6 (11.3) ppb during the lockdown and 66.4 (median: 60.5), 18.5 (24.5), and 2.99 (4.10) pbb at the post-lockdown period for Jubail, Rakah, and IAU stations, respectively. As a result of this reduction trend because of the lockdown measures, the mean $\mathrm{NO}_{2}$ concentrations in the prelockdown period at Jubail $\left(155 \mu \mathrm{g} / \mathrm{m}^{-3}\right)$, Rakah $(57.2 \mu \mathrm{g} /$ 

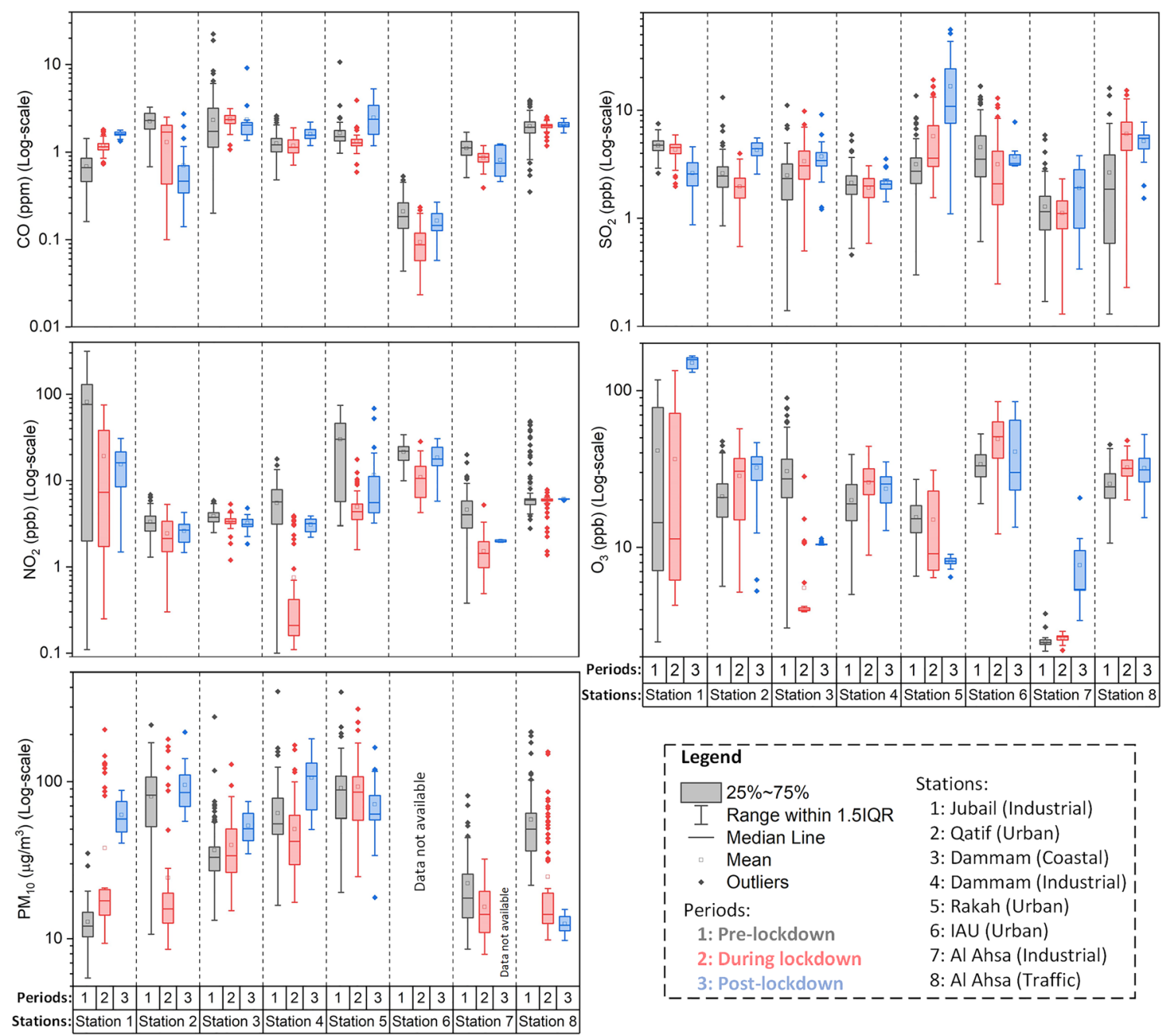

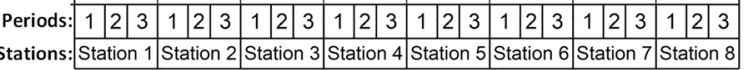

(n)

\begin{tabular}{ll} 
Legend & Stations: \\
\hline 25\% 75\% & 1: Jubail (Industrial) \\
\hline Median Line & 2: Qatif (Urban) \\
3: Dammam (Coastal) \\
4: Dammam (Industrial) \\
2: Priods: \\
2: During lockdown & 7: Al Ahsa (Industrial) \\
\hline 3: Post-lockdown & 8: Al Ahsa (Traffic)
\end{tabular}

Fig. 3 Box and whisker plots of daily average $\mathrm{CO}, \mathrm{SO}_{2}, \mathrm{NO}_{2}, \mathrm{O}_{3}$, and $\mathrm{PM}_{10}$ concentrations within the periods of pre-lockdown, during lockdown, and post-lockdown

$\mathrm{m}^{-3}$ ), and IAU $\left(40.8 \mu \mathrm{g} / \mathrm{m}^{-3}\right)$ sites, being higher than WHO's $\mathrm{NO}_{2}$ guideline value of $40 \mu \mathrm{g} / \mathrm{m}^{-3}$, reduced to $27.8,20.9$, and $33.4 \mu \mathrm{g} / \mathrm{m}^{-3}$ even after the lockdown period. The other possible explanations for the $\mathrm{NO}_{2}$ concentration decline rather than the significantly reduced transportation activities during the lockdown period might be attributed to the decrease in NO emission rate and/or the photolysis reaction of $\mathrm{NO}_{2}$. The high combustion processes, including automobile engines, generally produce about $>80 \%$ of $\mathrm{NO}$ and $<20 \%$ of $\mathrm{NO}_{2}$. Therefore, the photochemical reaction of $\mathrm{NO}_{2}$ to produce $\mathrm{O}_{3}$ and quite limited $\mathrm{NO}$ emissions to form $\mathrm{NO}_{2}$ may be the reasons for the observed declines in $\mathrm{NO}_{2}$ concentrations due to the lockdown.

Compared with the pre-lockdown phase, the mean $\mathrm{O}_{3}$ concentration decreased considerably at the Dammam-Coastal site by $\downarrow 25.1 \mathrm{ppb}$ and $\downarrow 20.1 \mathrm{ppb}$ during and after lockdown phases, respectively. The mean $\mathrm{O}_{3}$ concentration at Jubail site decreased from $46.5 \mathrm{ppb}$ (median: $14.3 \mathrm{ppb}$ ) to $36.4 \mathrm{ppb}$ $(11.3 \mathrm{ppb})$ due to lockdown and after the lockdown increased to $150 \mathrm{ppb}\left(282 \mu \mathrm{g} / \mathrm{m}^{-3}\right)$, which was quite above the WHO's 8-h daily maximum guideline value of $40 \mu \mathrm{g} / \mathrm{m}^{-3}$. In the other five monitoring sites, the mean $\mathrm{O}_{3}$ concentrations during and after lockdown periods showed a clear upward trend at varying levels. This result is corroborated with recently published studies focused on the effect of lockdown measures to combat COVID-19 on the air quality of Delhi (India) (Mahato et al. 2020), Almaty (Kazakhstan) (Kerimray et al. 2020), Barcelona (Spain) (Tobías et al. 2020), São Paulo (Brazil) (Nakada and Urban 2020), Wuhan (China) (Lian et al. 2020), and Hangzhou (China) (Wang et al. 2020). In these cited studies, the increasing trend of $\mathrm{O}_{3}$ against imposed lockdown measures was linked to (i) sharp drop of $\mathrm{NO}_{\mathrm{x}}$ emissions in lockdown period decreasing the possibility of $\mathrm{NO}+\mathrm{O}_{3}$ titration reaction, (ii) increased $\mathrm{VOC} / \mathrm{NO}_{\mathrm{x}}$ ratio because of more reduced $\mathrm{NOx}$ emission enhancing $\mathrm{O}_{3}$ production, and (iii) stronger solar radiation compared with pre-lockdown period favoring $\mathrm{O}_{3}$ formation and accumulation. These three explanations on why $\mathrm{O}_{3}$ concentrations increased against 
lockdown measures are also valid for the Eastern Province where: (i) $\mathrm{NO}_{2}$ concentrations remarkably decreased at all sites, (ii) fugitive VOC emissions from continuously operating petrochemical/chemical manufacturing facilities and oil refineries, and (iii) increasing solar radiation throughout the season (pre-lockdown average: $7982 \mathrm{~W} / \mathrm{m}^{2}$ day; lockdown: $12,000 \mathrm{~W} / \mathrm{m}^{2}$ day; and post-lockdown: 13,681 W/m² day).

The $\mathrm{PM}_{10}$ pollutant demonstrated the highest number of outliers among other pollutants during the whole study period. The number of $\mathrm{PM}_{10}$ outliers ( $>1.5 \mathrm{IQR}$ ) during lockdown is the highest for Jubail, Qatif, and Al Ahsa-Traffic sites. In addition, the mean values were significantly above the median values for most of the $\mathrm{PM}_{10}$ sampling locations during this study. The effect of lockdown on $\mathrm{PM}_{10}$ pollution was most apparent on Qatif, Dammam-Industrial, and Al Ahsa-Traffic sites where the mean concentrations reduced from 80.3 (median: 82.2) to $24.4(15.5) \mu \mathrm{g} / \mathrm{m}^{-3}$, from 63.0 (54.1) to 49.8 (41.9) $\mathrm{\mu g} / \mathrm{m}^{-3}$, and from 57.4 (50.1) to 24.8 (13.7) $\mu \mathrm{g} / \mathrm{m}^{-3}$, respectively, and became below the WHO's $\mathrm{PM}_{10}$ guideline value of $50 \mu \mathrm{g} / \mathrm{m}^{-3}$. The mean $\mathrm{PM}_{10}$ concentrations at Jubail, Dammam-Coastal, and Rakah sites did not indicate a decreasing trend during the lockdown, implying that these sites might be under the effect of a wide range of $\mathrm{PM}_{10}$ emission sources.

\section{Source apportionment of air pollutants by bivariate polar plots}

Bivariate polar plots depicted in Fig. 4 illustrate the joint effect of wind velocity and wind direction on the levels of air pollutants monitored at Rakah station before, during, and after lockdown periods. The radius, angle, and colored contour on the polar graphs represent wind velocity $(0-9 \mathrm{~m} / \mathrm{s})$, wind direction (0-360 in degrees), and concentration of the pollutant, respectively. The Rakah station was selected based on the extent of air pollution level relative to other stations. The main local air pollution sources in the vicinity of Rakah urban monitoring station are nearby traffic with moderate volume and extensive excavation/construction activities for the new residential area at southwest, King Abdulaziz Seaport in the north $(4 \mathrm{~km})$, and Industrial Area I at the west $(4 \mathrm{~km})$. Concentrations of $\mathrm{CO}$ and $\mathrm{SO}_{2}$ indicated similar distribution patterns on bivariate polar plots. Northerly winds with moderate speed and southerly winds with low speed usually brought higher $\mathrm{CO}$ and $\mathrm{SO}_{2}$ concentrations before and during the lockdown. After the lockdown, both $\mathrm{CO}$ and $\mathrm{SO}_{2}$ concentrations remarkably increased, and high concentrations corresponding to the winds blowing from all directions with low speeds $(<4 \mathrm{~m} / \mathrm{s})$ point out local sources. The relatively calm and low-speed wind conditions compared with before and during lockdown might be the reason to carry plumes of a large number of vehicles and machinery operating at the nearby construction site using diesel fuel with high sulfur content. The $\mathrm{NO}_{2}$ concentrations showed the maximum decrease during the lockdown phase among other pollutants since the main source for $\mathrm{NO}_{2}$ emissions is the on-road traffic, which was drastically reduced. The winds blowing from southwestern and northeastern sectors at varying speeds carried high $\mathrm{NO}_{2}$ levels to the monitoring site before and after lockdown phases. The concentration contour distribution of $\mathrm{O}_{3}$ demonstrated an opposite pattern to that of $\mathrm{NO}_{2}$ within the prelockdown period due to the scavenging effect of $\mathrm{NO}_{2}$ on $\mathrm{O}_{3}$ ( $\mathrm{NO}+\mathrm{O}_{3}$ titration reaction). The mean $\mathrm{O}_{3}$ concentration during lockdown was almost the same as pre-lockdown and decreased by $7.21 \mathrm{ppb}$ after the lockdown. This variation trend could be ascribed to the balanced $\mathrm{VOC} / \mathrm{NO}_{\mathrm{x}}$ ratio because of the VOC-limited characteristics of the Rakah area, which did not result in increasing $\mathrm{O}_{3}$ concentrations during and after lockdown periods as observed for other five sites in the Eastern Province. $\mathrm{PM}_{10}$ concentration distribution patterns on bivariate polar plots before and during lockdown were almost similar. The northwesterly and southerly winds with variable speeds carried high $\mathrm{PM}_{10}$ emissions to the monitoring site. Within the whole study period, the highest $\mathrm{PM}_{10}$ concentrations were observed when the wind speed was above $3 \mathrm{~m} / \mathrm{s}$, pointing the enhanced resuspension of dust and sand particles from open lands nearby and the possibility of regional/longrange transport. Interestingly, the mean $\mathrm{PM}_{10}$ concentration during the post-lockdown period reduced by $19.2 \mu \mathrm{g} / \mathrm{m}^{-3}$ as compared with pre-lockdown, which could be explained by changes in source emission rates, meteorological conditions, and atmospheric stability at Rakah area.

\section{Percent changes of air pollution levels during and after lockdown}

The percent changes in the concentrations of criteria air pollutants monitored at each station during and after the lockdown in reference to before lockdown are depicted in Fig. 5. The air quality improvements at Qatif-Industrial, DammamIndustrial, IAU-Urban, and Al Ahsa-Industrial sites were more evident as compared with the other three sites, and the response level of each site was quite different against same lockdown measures. The most pronounced decrease was found for $\mathrm{NO}_{2}$ since $\mathrm{NO}_{2}$ concentrations reduced at all sites during the lockdown and after lockdown as well. Within the lockdown phase, the highest $\mathrm{NO}_{2}$ reduction rate was noticed at Dammam-Industrial site (86\%), and followed by Rakah (84\%), Jubail (77\%), and Al Ahsa-Industrial (67\%) while the reduction rates were less than $50 \%$ at other sites: IAU (49\%) Al Ahsa-Traffic (34\%), Qatif (26\%), and DammamCoastal (12\%). After the lockdown, $\mathrm{NO}_{2}$ concentrations also dropped at all sites within the range between $14 \%$ (IAU) and $81 \%$ (Jubail).

In response to decreasing $\mathrm{NO}_{2}$ emission during lockdown period, changes in $\mathrm{CO}$ concentrations demonstrated decreasing trends most obviously at IAU (55\%) and Qatif (42\%) 


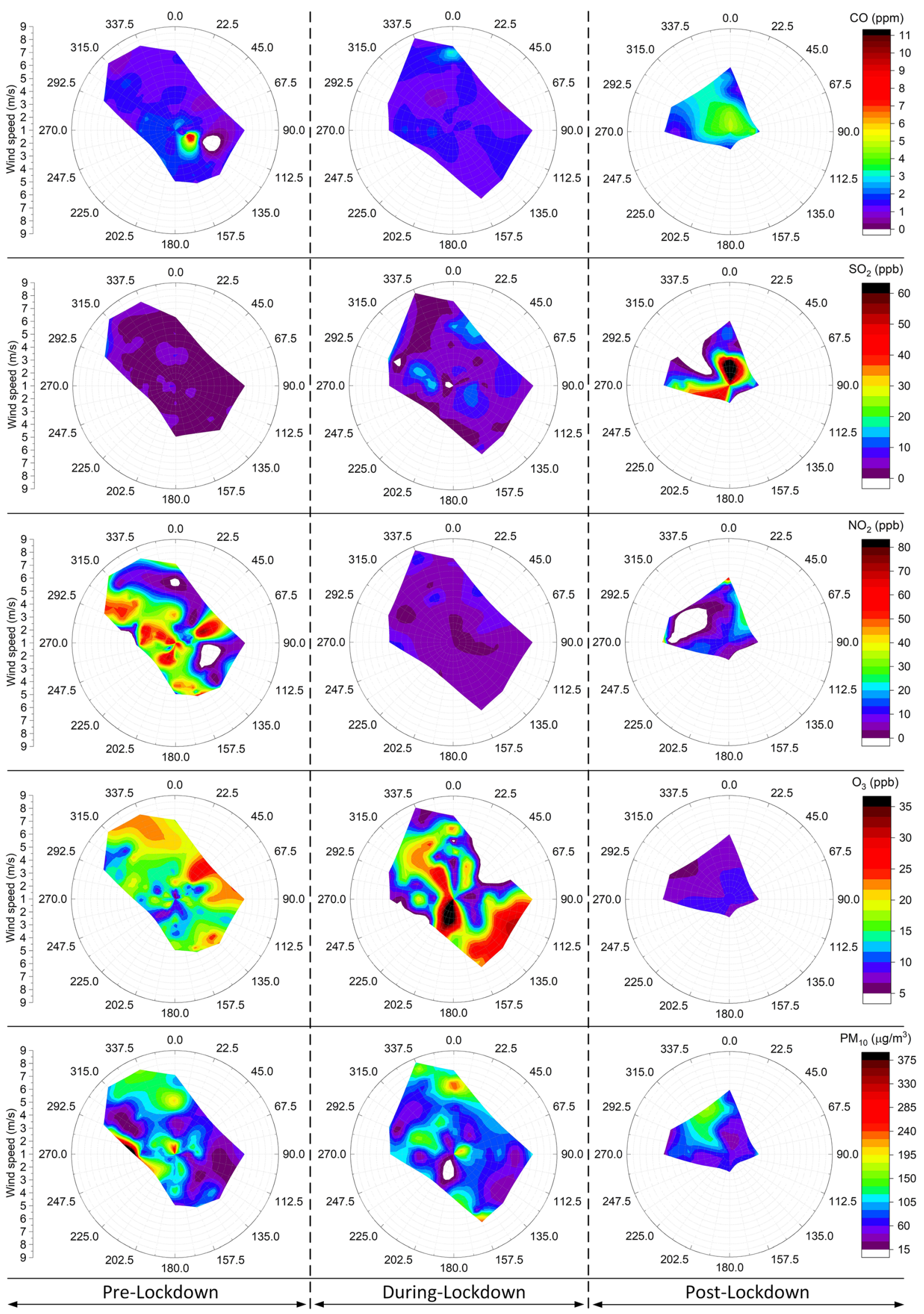

Fig. 4 Bivariate polar plots illustrating the joint effect of wind velocity and wind direction on observed pollutants at Rakah station 
urban sites and then followed by Al Ahsa-Industrial (22\%), Rakah-Urban (20\%), and Dammam-Industrial (5.8\%) sites. During the post-lockdown phase, Qatif and IAU urban stations and Al Ahsa-Industrial site indicated decreasing $\mathrm{CO}$ rates of $69 \%, 22 \%$, and $27 \%$, respectively. These results reveal that the $\mathrm{CO}$ and $\mathrm{NO}_{2}$ were commonly emitted from transportation activities, which were limited significantly during the lockdown and partially within post-lockdown phases,

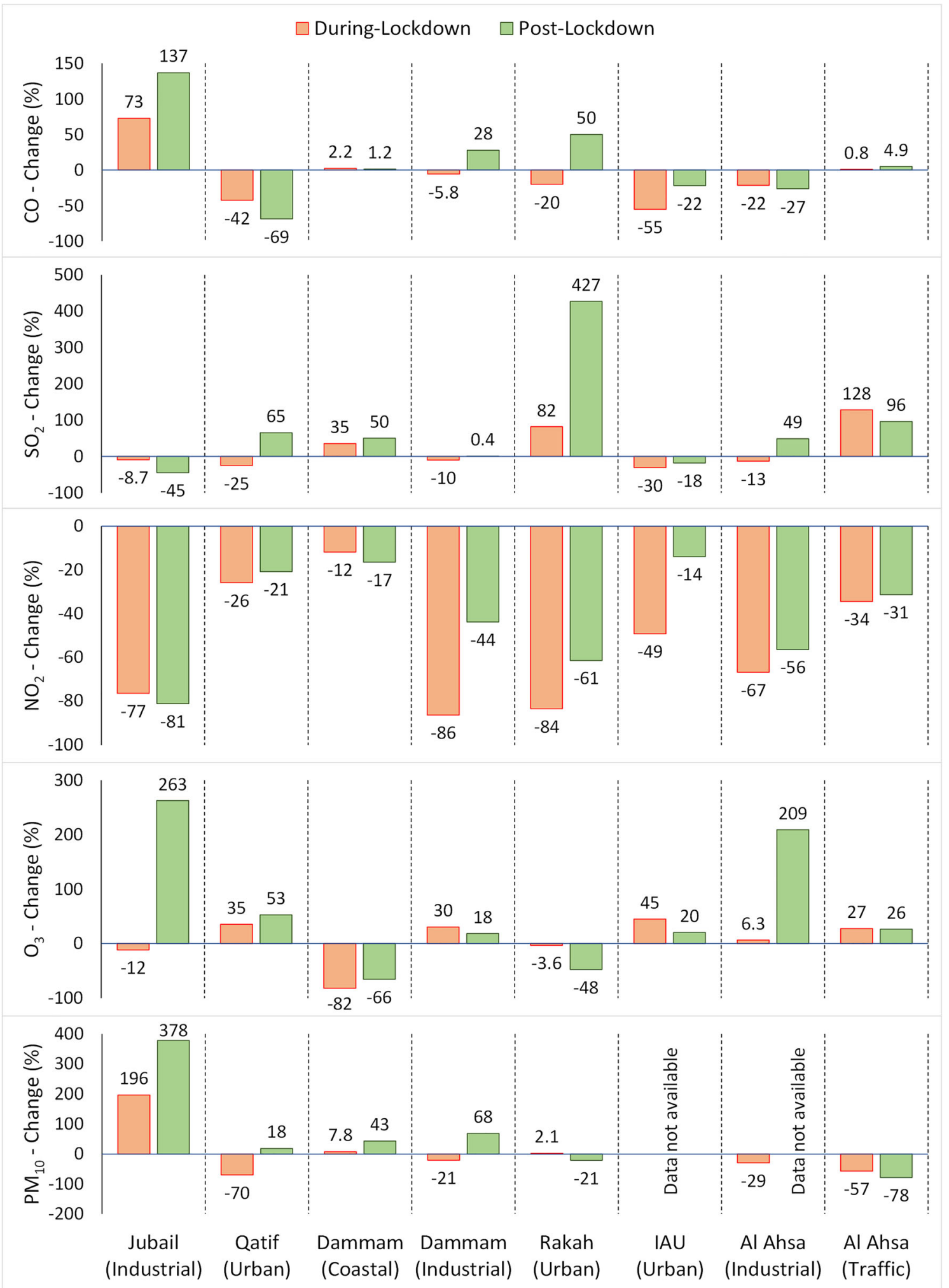

Fig. 5 Percent changes in air pollution levels during COVID-19 pandemic compared with pre-lockdown period 
especially at urban locations. On the other hand, the CO level at Jubail industrial site gradually increased by $73 \%$ and $137 \%$ during and after lockdown, respectively. These remarkable $\mathrm{CO}$ increase rates could be attributed to the huge and wide range of industrial activities with variable production capacities that did not respond as expected against imposed lockdown measures at the Jubail industrial city.

The ground level $\mathrm{O}_{3}$ is classified as a secondary pollutant, and its complex formation mechanism is governed by NOx and $\mathrm{VOC}$ emissions, $\mathrm{VOC} / \mathrm{NO}_{\mathrm{X}}$ ratio in the atmosphere, the strength of solar radiation, and atmospheric stability (Xu et al. 2020). In addition to this, the $\mathrm{O}_{3}$ concentration at a receptor point could be under the effect of long-range transport mechanism as the atmospheric lifetime of $\mathrm{O}_{3}$ is about 22 days ( $\mathrm{Li}$ et al. 2020; Sicard et al. 2020). Contrary to the significant reduction rates in $\mathrm{NO}_{2}$ during and after the lockdown, increasing $\mathrm{O}_{3}$ rates occurred at most of the sites, ranging between 6.3 and $45 \%$ within lockdown and between 18 and $263 \%$ after lockdown. This increasing pattern might be linked to the substantially dropped $\mathrm{NO}_{\mathrm{x}}$ emissions (reduction in titration impact on $\mathrm{O}_{3}$ ), increased $\mathrm{VOC} / \mathrm{NO}_{\mathrm{x}}$ ratios, and stronger solar radiation as compared with before lockdown period. The highest increase rates after lifting lockdown measures were monitored at Jubail (263\%) and Al Ahsa (209\%) industrial sites where decreases in VOC emissions from a large number of petrochemical factories and large oil plants/refineries were not as large as $\mathrm{NO}_{\mathrm{x}}$ emissions, most probably leading to an enhanced formation of $\mathrm{O}_{3}$ under stronger solar radiation and more stable atmospheric conditions.

The decrease rate of $\mathrm{SO}_{2}$ during the lockdown period was in the following order of $30 \%$ (IAU) $>25 \%$ (Qatif) $>13 \%$ (Al Ahsa-Industrial) $>10 \%$ (Dammam-Industrial) $>8.7 \%$ (Jubail). After lifting the lockdown, Jubail and IAU sites showed $45 \%$ and $18 \%$ reduction rates, respectively, while other sites indicated increasing $\mathrm{SO}_{2}$ ratios varied between 50 and $427 \%$. The Rakah station showed the most significant $\mathrm{SO}_{2}$ increase rates of $82 \%$ and $427 \%$ during the lockdown and after lockdown, respectively. The highest $\mathrm{SO}_{2}$ increase among other stations after lockdown may be ascribed to new excavation and dredging activities in the nearby residential area of the Rakah site.

Even though the Eastern Province is under the effect of a wide range of $\mathrm{PM}_{10}$ emissions, the decreasing $\mathrm{PM}_{10}$ trend noticed in Qatif (70\%), followed by Al Ahsa-Trafic (57\%), AlAhsa-Industrial (29\%), and Dammam-Industrial (21\%) stations is an evidence for the effect of lockdown measures. In contrary to that, the Jubail station showed the most significant increases of $196 \%$ and $378 \%$ during and after lockdown, respectively. This remarkable increase compared with other sites may be attributed to local dust storm conditions since the Jubail station is approximately $180 \mathrm{~km}$ and $60 \mathrm{~km}$ far north from Al Ahsa and Qatif/Dammam monitoring stations, respectively.
The observed reduction trends in $\mathrm{NO}_{2}$ (all sites), $\mathrm{CO}$ (Qatif-Urban, IAU-Urban, and $\mathrm{Al}$ Ahsa-Industrial), $\mathrm{SO}_{2}$ (Jubail-Industrial and IAU-Urban), and $\mathrm{PM}_{10}$ (Al AhsaTrafic and Rakah-Urban) pollutants even after releasing the lockdown measures could possibly be attributed to the multiple factors: (i) preference of people staying home due to the fear of the pandemic, (ii) allowing employees work from home by most of the companies, (iii) partial or full halt of production in some factories because of shattered supply chains, and (iv) different meteorological conditions and atmospheric stabilities compared with post-lockdown period.

\section{Comparison with other regions}

The variations of pollutant concentrations due to COVID-19 lockdown in different countries around the world are shown in Table 1 . The median values of percent changes in each pollutant monitored at the Eastern Province demonstrated in Table 1 are in a good agreement with those reported for the compared sites. The CO concentrations showed decreasing rates for all monitoring stations around the world. The major change in $\mathrm{CO}$ was observed for Almaty (Kazakhstan) from March 19 to April 14, with a percentage reduction of $49 \%$. The same trend was observed in this study, where the median reduction value of CO was 13\% during March 23 and June 21. The same similar trend was observed for $\mathrm{NO}_{2}$. All monitoring stations showed significant decreases during lockdown compared with the pre-lockdown period. The highest $\mathrm{NO}_{2}$ reduction was reported to be $96 \%$ for Sale (Morocco) from March 21 to April 2. On the other hand, $\mathrm{O}_{3}$ showed an increasing concentration trend in all compared sites around the world, including our study, except for the Anqing, Hefei, and Suzhou areas of China, which indicated a reduction of $9.6 \%$. The changes in $\mathrm{SO}_{2}$ concentrations fluctuated between $-53 \%$ (China) and $8 \%$ (São Paulo, Brazil), while $\mathrm{PM}_{10}$ concentration changes varied between $-75 \%$ (Salé, Morocco) and $19 \%$ (Rome, Italy). Besides, $\mathrm{SO}_{2}$ and $\mathrm{PM}_{10}$ pollutants demonstrated decreasing trends at $75 \%$ of the locations compared in Table 1.

\section{Conclusions}

In this work, the possible effects of the lockdown due to the COVID-19 pandemic on the air quality were investigated in an arid region using meteorological and air quality datasets obtained from eight monitoring stations covering the Eastern Province of the KSA within the period between September 15, 2019, and July 18, 2020. The mean concentrations of $\mathrm{NO}_{2}$ and $\mathrm{PM}_{10}$ pollutants at several monitoring stations reduced to such levels lower than the guideline values of WHO by virtue of the imposed lockdown, which might reduce the impact of COVID-19, especially on elderly and sensitive groups. The 
Table 1 Variations of pollutant concentration due to COVID-19 control measures in different locations

\begin{tabular}{|c|c|c|c|c|c|c|c|}
\hline \multirow[t]{2}{*}{ Location } & \multirow{2}{*}{$\begin{array}{l}\text { Studied } \\
\text { lockdown } \\
\text { period }\end{array}$} & \multicolumn{5}{|c|}{$\begin{array}{l}\text { Change of pollutant concentration due to } \\
\text { COVID-19 control measures }(\%)\end{array}$} & \multirow[t]{2}{*}{ Reference } \\
\hline & & $\mathrm{CO}$ & $\mathrm{SO}_{2}$ & $\mathrm{NO}_{2}$ & $\mathrm{O}_{3}$ & $\mathrm{PM}_{10}$ & \\
\hline Tehran (Iran) & $\begin{array}{l}\text { Mar. } \\
21-\text { Apr. } 21\end{array}$ & -41 & -28 & -33 & 103 & -30 & $\begin{array}{l}\text { (Broomandi } \\
\quad \text { et al. 2020) }\end{array}$ \\
\hline Delhi (India) & $\begin{array}{l}\text { Mar. } \\
24-A p r .11\end{array}$ & -30 & -18 & -53 & 0.8 & -52 & $\begin{array}{l}\text { (Mahato et al. } \\
\text { 2020) }\end{array}$ \\
\hline $\begin{array}{l}\text { Almaty } \\
\text { (Kazakhstan) }\end{array}$ & $\begin{array}{l}\text { Mar. } \\
19-\text { Apr. } 14\end{array}$ & -49 & 7 & -35 & 15 & n.a. & $\begin{array}{l}\text { (Kerimray et al. } \\
2020)\end{array}$ \\
\hline Salé (Morocco) & Mar. 21-Apr. 2 & n.a. & -49 & -96 & n.a. & -75 & $\begin{array}{l}\text { (Otmani et al. } \\
\text { 2020) }\end{array}$ \\
\hline Barcelona (Spain) & $\begin{array}{l}\text { Mar. 14-Mar. } \\
\quad 30\end{array}$ & n.a. & 1.8 & -51 & 58 & -31 & $\begin{array}{l}\text { (Tobías et al. } \\
\text { 2020) }\end{array}$ \\
\hline São Paulo (Brazil) & $\begin{array}{l}\text { Mar. } \\
24-\text { Apr. } 20\end{array}$ & -30 & 8 & -22 & 11 & 7.7 & $\begin{array}{l}\text { (Nakada and } \\
\text { Urban 2020) }\end{array}$ \\
\hline $\begin{array}{l}\text { Nice (France) } \\
\text { Rome (Italy) }\end{array}$ & Mar.-Apr. & $\begin{array}{l}\text { n.a. } \\
\text { n.a. }\end{array}$ & $\begin{array}{l}\text { n.a. } \\
\text { n.a. }\end{array}$ & $\begin{array}{l}-63 \\
-46\end{array}$ & $\begin{array}{l}24 \\
14\end{array}$ & $\begin{array}{l}-7.8 \\
19\end{array}$ & $\begin{array}{l}\text { (Sicard et al. } \\
\text { 2020) }\end{array}$ \\
\hline Turin (Italy) & & n.a. & n.a. & -30 & 27 & 9.9 & \\
\hline Valencia (Spain) & & n.a. & n.a. & -70 & 2.4 & 15 & \\
\hline Wuhan (China) & & n.a. & n.a. & -57 & 36 & -32 & \\
\hline Wuhan (China) & Jan. 23-Feb. 23 & -23 & -3.9 & -53 & 117 & -40 & $\begin{array}{l}\text { (Lian et al. } \\
\text { 2020) }\end{array}$ \\
\hline Hangzhou (China) & Jan. 24-Feb. 15 & -22 & -29 & -58 & 145 & -48 & $\begin{array}{l}\text { (Wang et al. } \\
\text { 2020) }\end{array}$ \\
\hline $\begin{array}{l}\text { Yangtze River } \\
\text { Delta Region } \\
\text { (China) }\end{array}$ & $\begin{array}{l}\text { Jan. 24-Feb. } 25 \\
\text { Feb. 26-Mar. } \\
\quad 31\end{array}$ & $\begin{array}{l}-39 \\
-25\end{array}$ & $\begin{array}{l}-26 \\
-15\end{array}$ & $\begin{array}{l}-47 \\
-29\end{array}$ & $\begin{array}{l}8.3 \\
2.3\end{array}$ & $\begin{array}{l}-61 \\
-36\end{array}$ & (Li et al. 2020) \\
\hline $\begin{array}{l}\text { Anqing, Hefei, and } \\
\text { Suzhou area } \\
\text { (China) }\end{array}$ & $\begin{array}{l}\text { Feb. 1-Feb. } 29 \\
\text { Mar. 1-Mar. } 31\end{array}$ & $\begin{array}{l}-36 \\
-24\end{array}$ & $\begin{array}{l}-53 \\
-41\end{array}$ & $\begin{array}{l}-53 \\
-27\end{array}$ & $\begin{array}{l}3.6 \\
-9.6\end{array}$ & $\begin{array}{l}-49 \\
-25\end{array}$ & (Xu et al. 2020) \\
\hline $\begin{array}{l}\text { Eastern Region } \\
\quad \text { (Saudi Arabia) }\end{array}$ & Mar. 23-Jun. 20 & $\begin{array}{r}-13 \\
( \pm \\
36)\end{array}$ & $\begin{array}{r}-9.2 \\
( \pm \\
54)\end{array}$ & $\begin{array}{r}-58 \\
( \pm \\
26)\end{array}$ & $\begin{array}{l}17 \\
\quad( \pm \\
38)\end{array}$ & $\begin{array}{r}-21 \\
( \pm \\
83)\end{array}$ & This study \\
\hline
\end{tabular}

$\mathrm{NO}_{2}$ was found to be the marker pollutant responding best to the lockdown measures since the concentration reductions of $\mathrm{NO}_{2}$ during- and post-lockdown periods at all sites ranged between $12-86 \%$ and $14-81 \%$, respectively. In parallel to decreases in the $\mathrm{NO}_{2}$ concentrations, drops in $\mathrm{CO}$ concentrations fluctuated between 5.8 and $55 \%$ considering most of the sites, suggesting that $\mathrm{CO}$ and $\mathrm{NO}_{2}$ emissions were mainly from transportation activities, which were substantially restricted during the lockdown phase. Interestingly, $\mathrm{O}_{3}$ concentrations increased at the majority of the monitoring stations, ranging between 6.3 and $45 \%$ within lockdown and between 18 and $263 \%$ after lockdown. The results also revealed that controlling the formation of ground-level $\mathrm{O}_{3}$ is a quite challenging task even by reducing the emissions of primary air pollutants significantly. The Eastern Province is a low- $\mathrm{SO}_{2}$ emitting region due to the stringent air pollution control regulations, and the monitored $\mathrm{SO}_{2}$ emissions have been quite below the national standards and WHO's guidelines. For this reason, the reductions in $\mathrm{SO}_{2}$ concentrations were not distinct and varied between 8.7 and $30 \%$ during the lockdown period. The effect of lockdown measures was also evident in $\mathrm{PM}_{10}$ concentrations, which reduced within the range between 21 and $70 \%$ at most of the sites even though a wide range of emission sources dominates the $\mathrm{PM}_{10}$ budget over the Eastern Province's atmosphere. Besides the damaging effects of COVID-19 pandemic, the imposed lockdown countermeasures have been a unique opportunity to investigate the effects of reduced emission rates of pollutants from various sources on the air quality, to evaluate the existing and future air quality control regulations, and to build short- and long-term alternative action plans to enhance the air quality.

Funding The authors acknowledge the funding provided by the Deanship of Scientific Research (DSR) at Imam Abdulrahman Bin Faisal University (IAU) in Saudi Arabia through research project No. 2018-044-Eng. 


\section{Compliance with ethical standards}

Conflict of interest The authors declare that they have no conflict of interest.

\section{References}

Agarwal A, Kaushik A, Kumar S, Mishra RK (2020) Comparative study on air quality status in Indian and Chinese cities before and during the COVID-19 lockdown period. Air Qual Atmos Heal. https://doi. org/10.1007/s11869-020-00881-z

Ahmadi M, Sharifi A, Dorosti S, Jafarzadeh Ghoushchi S, Ghanbari N (2020) Investigation of effective climatology parameters on COVID-19 outbreak in Iran. Sci Total Environ 729:138705. https://doi.org/10.1016/j.scitotenv.2020.138705

Anil I, Alagha O, Karaca F (2017) Effects of transport patterns on chemical composition of sequential rain samples: trajectory clustering and principal component analysis approach. Air Qual Atmos Heal 10: 1193-1206. https://doi.org/10.1007/s11869-017-0504-x

Anil I, Alagha O, Blaisi NI, Mohamed IA, Barghouthi MH, Manzar MS (2019) Source identification of episodic rain pollutants by new approach: combining satellite observations and backward air mass trajectories. Aerosol Air Qual Res 9:2827-2843. https://doi.org/10. 4209/aaqr.2019.04.0187

Barbieri DM, Lou B, Passavanti M, et al (2020) Survey data regarding perceived air quality in Australia, Brazil, China, Ghana, India, Iran, Italy, Norway, South Africa, United States before and during COVID-19 restrictions. Data Br 106169. https://doi.org/10.1016/j. dib.2020.106169

Bashir MF, Ma B, Shahzad L (2020a) A brief review of socio-economic and environmental impact of Covid-19. Air Qual Atmos Heal. https://doi.org/10.1007/s11869-020-00894-8

Bashir MF, Ma BJ, Bilal Ma BJ, Bilal, Komal B, Bashir MA, Farooq TH, Iqbal N, Bashir M (2020b) Correlation between environmental pollution indicators and COVID-19 pandemic: a brief study in Californian context. Environ Res 187:109652. https://doi.org/10. 1016/j.envres.2020.109652

Berman JD, Ebisu K (2020) Changes in U.S. air pollution during the COVID-19 pandemic. Sci Total Environ 739:139864. https://doi. org/10.1016/j.scitotenv.2020.139864

Bherwani H, Nair M, Musugu K, Gautam S, Gupta A, Kapley A, Kumar R (2020) Valuation of air pollution externalities: comparative assessment of economic damage and emission reduction under COVID-19 lockdown. Air Qual Atmos Heal 13:683-694. https:// doi.org/10.1007/s11869-020-00845-3

Broomandi P, Karaca F, Nikfal A, Jahanbakhshi A, Tamjidi M, Kim JR (2020) Impact of COVID-19 event on the air quality in Iran. Aerosol Air Qual Res 20:1793-1804. https://doi.org/10.4209/aaqr.2020.05. 0205

EU (2008) Directive 2008/50/EC of the European Parliament and of the Council on ambient air quality and cleaner air for Europe. Brussels, Belgium

Fareed Z, Iqbal N, Shahzad F, Shah SGM, Zulfiqar B, Shahzad K, Hashmi SH, Shahzad U (2020) Co-variance nexus between COVID-19 mortality, humidity, and air quality index in Wuhan, China: New insights from partial and multiple wavelet coherence. Air Qual Atmos Heal 13:673-682. https://doi.org/10.1007/s11869020-00847-1

Farhan Bashir M, Benghoul M, Numan U et al (2020) Environmental pollution and COVID-19 outbreak: insights from Germany. Air Qual Atmos Heal.:1-10. https://doi.org/10.1007/s11869-02000893-9
Gautam S (2020) COVID-19: air pollution remains low as people stay at home. Air Qual Atmos Heal 13:853-857. https://doi.org/10.1007/ s11869-020-00842-6

Habeebullah TM, Munir S, Awad AHAA et al (2015) The interaction between air quality and meteorological factors in an arid environment of Makkah, Saudi Arabia. Int J Environ Sci Dev 6:576-580. https://doi.org/10.7763/IJESD.2015.V6.660

Karaca F, Anil I, Alagha O (2009) Long-range potential source contributions of episodic aerosol events to PM10 profile of a megacity. Atmos Environ 43:5713-5722. https://doi.org/10.1016/j.atmosenv. 2009.08.005

Kerimray A, Baimatova N, Ibragimova OP, Bukenov B, Kenessov B, Plotitsyn P, Karaca F (2020) Assessing air quality changes in large cities during COVID-19 lockdowns: the impacts of traffic-free urban conditions in Almaty, Kazakhstan. Sci Total Environ 730: 139179. https://doi.org/10.1016/j.scitotenv.2020.139179

Li L, Li Q, Huang L, Wang Q, Zhu A, Xu J, Liu Z, Li H, Shi L, Li R, Azari M, Wang Y, Zhang X, Liu Z, Zhu Y, Zhang K, Xue S, Ooi MCG, Zhang D, Chan A (2020) Air quality changes during the COVID-19 lockdown over the Yangtze River Delta Region: an insight into the impact of human activity pattern changes on air pollution variation. Sci Total Environ 732:139282. https://doi.org/ 10.1016/j.scitotenv.2020.139282

Lian X, Huang J, Huang R, Liu C, Wang L, Zhang T (2020) Impact of city lockdown on the air quality of COVID-19-hit of Wuhan City. Sci Total Environ 742:140556. https://doi.org/10.1016/j.scitotenv. 2020.140556

Mahato S, Pal S, Ghosh KG (2020) Effect of lockdown amid COVID-19 pandemic on air quality of the megacity Delhi, India. Sci Total Environ 730:139086. https://doi.org/10.1016/j.scitotenv.2020. 139086

$\mathrm{MoH}$ (2020) Kingdom of Saudi Arabia - Ministry of Health Portal

Nadzir MSM, Ooi MCG, Alhasa KM et al (2020) The impact of movement control order (MCO) during pandemic COVID-19 on local air quality in an urban area of Klang valley, Malaysia. Aerosol Air Qual Res 20:1237-1248. https://doi.org/10.4209/aaqr.2020.04.0163

Nakada LYK, Urban RC (2020) COVID-19 pandemic: impacts on the air quality during the partial lockdown in São Paulo state, Brazil. Sci Total Environ 730:139087. https://doi.org/10.1016/j.scitotenv.2020. 139087

Omokungbe OR, Fawole OG, Owoade OK, Popoola OAM, Jones RL, Olise FS, Ayoola MA, Abiodun PO, Toyeje AB, Olufemi AP, Sunmonu LA, Abiye OE (2020) Analysis of the variability of airborne particulate matter with prevailing meteorological conditions across a semi-urban environment using a network of low-cost air quality sensors. Heliyon 6:e04207. https://doi.org/10.1016/j. heliyon.2020.e04207

Otmani A, Benchrif A, Tahri M, Bounakhla M, Chakir EM, el Bouch M, Krombi M' (2020) Impact of Covid-19 lockdown on PM10, SO2 and NO2 concentrations in Salé City (Morocco). Sci Total Environ 735:139541. https://doi.org/10.1016/j.scitotenv.2020.139541

Pata UK (2020) How is COVID-19 affecting environmental pollution in US cities? Evidence from asymmetric Fourier causality test. Air Qual Atmos Heal. https://doi.org/10.1007/s11869-020-00877-9

Shakoor A, Chen X, Farooq TH, Shahzad U, Ashraf F, Rehman A, Sahar N, Yan W (2020) Fluctuations in environmental pollutants and air quality during the lockdown in the USA and China: two sides of COVID-19 pandemic. Air Qual Atmos Heal. https://doi.org/10. 1007/s11869-020-00888-6

Sharma M, Jain S, Lamba BY (2020) Epigrammatic study on the effect of lockdown amid Covid-19 pandemic on air quality of most polluted cities of Rajasthan (India). Air Qual Atmos Heal. https://doi.org/10. 1007/s11869-020-00879-7

Shehzad K, Sarfraz M, Shah SGM (2020) The impact of COVID-19 as a necessary evil on air pollution in India during the lockdown. 
Environ Pollut 266:115080. https://doi.org/10.1016/j.envpol.2020. 115080

Sicard P, De Marco A, Agathokleous E et al (2020) Amplified ozone pollution in cities during the COVID-19 lockdown. Sci Total Environ 735:139542. https://doi.org/10.1016/j.scitotenv.2020. 139542

Singh RP, Chauhan A (2020) Impact of lockdown on air quality in India during COVID-19 pandemic. Air Qual Atmos Heal 13:921-928. https://doi.org/10.1007/s11869-020-00863-1

Tawabini BS, Lawal TT, Shaibani A, Farahat AM (2017) Morphological and chemical properties of particulate matter in the Dammam Metropolitan Region: Dhahran, Khobar, and Dammam, Saudi Arabia. Adv Meteorol 2017:1-9. https://doi.org/10.1155/2017/ 8512146

Tobías A, Carnerero C, Reche C, Massagué J, Via M, Minguillón MC, Alastuey A, Querol X (2020) Changes in air quality during the lockdown in Barcelona (Spain) one month into the SARS-CoV-2 epidemic. Sci Total Environ 726:138540. https://doi.org/10.1016/j. scitotenv.2020.138540

Tsiouri V, Kakosimos KE, Kumar P (2015) Concentrations, sources and exposure risks associated with particulate matter in the Middle East Area-a review. Air Qual Atmos Heal 8:67-80. https://doi.org/10. 1007/s11869-014-0277-4
Wang L, Li M, Yu S, Chen X, Li Z, Zhang Y, Jiang L, Xia Y, Li J, Liu W, Li P, Lichtfouse E, Rosenfeld D, Seinfeld JH (2020) Unexpected rise of ozone in urban and rural areas, and sulfur dioxide in rural areas during the coronavirus city lockdown in Hangzhou, China: implications for air quality. Environ Chem Lett. https://doi.org/10. 1007/s10311-020-01028-3

WHO (2006) WHO Air quality guidelines for particulate matter, ozone, nitrogen dioxide and sulfur dioxide, Global update 2005, Summary of risk assessment. World Health Organization, Geneva

WHO (2020) Coronavirus disease (COVID-19). https://www.who.int/ emergencies/diseases/novel-coronavirus-2019. Accessed 27 Jul 2020

Xu K, Cui K, Young L-H, Wang YF, Hsieh YK, Wan S, Zhang J (2020) Air quality index, indicatory air pollutants and impact of COVID-19 event on the air quality near Central China. Aerosol Air Qual Res 20:1204-1221. https://doi.org/10.4209/aaqr.2020.04.0139

Zambrano-Monserrate MA, Ruano MA (2020) Has air quality improved in Ecuador during the COVID-19 pandemic? A parametric analysis. Air Qual Atmos Heal 13:929-938. https://doi.org/10.1007/s11869020-00866-y

Publisher's note Springer Nature remains neutral with regard to jurisdictional claims in published maps and institutional affiliations. 